\title{
DIRECT POWER CONTROL OF A DFIG-BASED WIND TURBINE UNDER UNBALANCED GRID VOLTAGE WITHOUT ROTOR POSITION SENSOR
}

\author{
Ali IZANLO, SAYyed ASghar GHOLAMIAN* AND MOHAMMAD VERIJ KAZEMI \\ Faculty of Electrical and Computer Engineering, \\ Babol Noshirvani University of Technology, Babol, Iran. \\ *Corresponding author: gholamian@nit.ac.ir \\ (Received: 24 ${ }^{\text {th }}$ Apr. 2016; Accepted: 20 th Jun. 2016; Published online: 30 th May 2017)
}

\begin{abstract}
In this paper, the behavior of a doubly fed induction generator (DFIG) is proposed under an unbalanced grid voltage and without using a rotor position sensor. There are two main methods that have been used for the detection of rotor position: use of a shaft sensor and use of a sensorless algorithm. In this paper the shaft sensor is eliminated and a position sensorless algorithm is used for estimating the rotor position. Sensorless operation is more desirable than using shaft sensors, because shaft sensors have several disadvantages related to cost, cabling, robustness, and maintenance. Also, during network imbalance, three selectable control targets are identified for the rotor side converter (RSC), i.e., obtaining sinusoidal and symmetrical stator currents, mitigation of active and reactive powers ripples and the cancellation of electromagnetic torque oscillations. The effectiveness of the proposed control strategy is confirmed by the simulation results from a 2-MW DFIG system. It is concluded that the sensorless algorithm is able to produce results with similar accuracy to shaft sensor use and the sensorless algorithm can be used in practical applications.
\end{abstract}

ABSTRAK: Dalam kertas ini, tingkah laku penjana induksi dua suapan (DFIG) dicadangkan di bawah voltan grid tidak seimbang dan tanpa menggunakan sensor kedudukan rotor. Dua kaedah utama telah digunakan untuk mengesan kedudukan rotor: penggunaan sensor shaf dan penggunaan algoritma tanpa sensor. Dalam kertas ini sensor shaf dihapuskan dan kedudukan algoritma tanpa sensor digunakan untuk menganggarkan kedudukan rotor. Operasi tanpa sensor jauh lebih baik dari menggunakan sensor shaf, kerana sensor shaf mempunyai beberapa kelemahan yang berkaitan dengan kos, pemasangan kabel, keteguhan, dan penyelenggaraan. Juga, dalam ketidakseimbangan rangkaian, tiga sasaran kawalan yang boleh dipilih telah dikenal pasti untuk converter rotor sisi (RSC), iaitu, mendapatkan arus stator sinusoidal dan simetri, pengurangan kuasa riak aktif dan reaktif dan pembatalan ayunan tork elektromagnet. Keberkesanan strategi kawalan yang dicadangkan disahkan oleh keputusan simulasi daripada sistem 2MW DFIG. Adalah dirumuskan bahawa algoritma tanpa sensor mampu menghasilkan keputusan dengan tepat sama seperti menggunakan sensor syaf dan algoritma tanpa sensor boleh digunakan dalam aplikasi praktikal.

KEYWORDS: double fed induction generator (DFIG); direct power control (DPC); unbalanced voltage; rotor position estimation

\section{INTRODUCTION}

Wind energy has become an important source for electricity generation in many countries. It is expected that wind energy will provide about $10 \%$ of the world's electrical energy in 2020. Nowadays, many wind farms are based on DFIG technology with 
converters that have generator ratings of $20 \%-30 \%$. In the global wind market, DFIG has become one of the most popular configurations. DFIG has several advantages including variable speed, four-quadrant active and reactive power operation capabilities, and decoupled active and reactive power control. It also allows the use of a partially rated converter which reduces system cost. A schematic diagram of the DFIG-based wind energy conversion systems is shown in Fig. 1 [1].

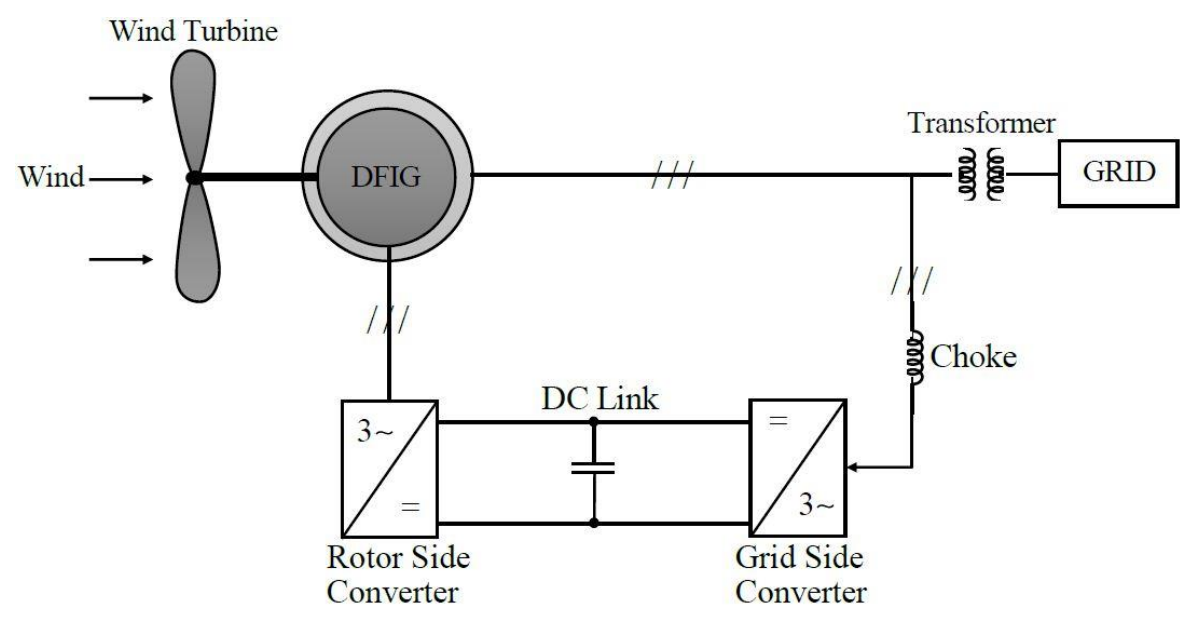

Fig. 1: Schematic diagram of DFIG-based wind energy systems.

The wind power system shown in Fig. 1 consists of a DFIG, where the stator winding is directly connected to the network and the rotor winding is connected to the network through a four-quadrant power converter comprised of two back-to-back pulse width modulation (PWM) voltage source inverters (VSI). Usually, the controller of the rotor side converter regulates the electromagnetic torque and supplies part of the reactive power to maintain the magnetization of the machine. On the other hand, the controller of the supply side converter regulates the DC link voltage. Traditionally, the techniques to control the rotor-side converter (RSC) and the grid-side converter (GSC) of DFIG-based wind turbines include vector control (VC) and direct torque control (DTC) or direct power control. The direct power control (DPC) for DFIG has been the focus of some studies [1][7] and proven to have several advantages over the conventional vector control strategy, such as simple implementation, fast dynamic response, and robustness to DFIG parameter variations.

In [1] a DPC strategy based on an optimal switching table that uses the estimated stator flux information was proposed. However, like a conventional DTC, DPC has a switching frequency that varies significantly with active and reactive power variations, the power controllers' hysteresis bandwidth, and the machine operating speed (rotor speed). As a result, this method complicates the AC filter design because of its variable switching frequency. Consequently, the DPC with space vector modulation (SVM) [2] and predictive control $[3,4]$ has been proposed to achieve a constant switching frequency. Sliding mode control (SMC) strategy is an effective and high frequency switching control for nonlinear systems with uncertainties. It features simple implementation, disturbance rejection, strong robustness and fast responses. Thus, a SMC based DPC drive for DFIG was proposed in [5]. Paper [6] presents the comparison of three different strategies for the control of a DFIG in wind energy conversion systems (WECS). These strategies are: vector control, direct torque control, and direct power control. In [7], switching vectors for the rotor side converter were selected from the optimal switching table using the estimated stator flux 
position and the errors of the active and reactive power. In this reference, the increased number of voltage vectors with application of the Discrete Space Vector Modulation (DSVM) will be presented. Then a new switching table in super-synchronous and subsynchronous frames will be proposed.

A simple position-sensorless method for rotor side field oriented control of a wound rotor induction machine is described in [8]. The algorithm is based on axis transformation. Compared to the other methods, it is more direct and the dependence on machine parameters is also largely reduced.

For most of the studies reported, a symmetrical stator voltage supply was assumed even during network disturbance. However, both transmission and distribution networks can have "small" steady states and "large" transient voltage unbalances. If DFIG control systems do not take into account the voltage unbalance, the stator currents can become highly unbalanced even with small voltage unbalances. The unbalanced currents create unequal heating on the stator windings. Subsequently, the pulsations with double grid frequency will be generated in the stator output active and reactive power, which are harmful to the stability of the connected power grid. Furthermore, the electromagnetic torque starts to oscillate at the double grid frequency, which will cause durative stress concussion to the rotor shaft and possible damage to the mechanical system of the wind turbine. It has been found that wind farms connected to distribution networks periodically experience voltage unbalances of greater than $2 \%$, and this has caused a large number of trips. More recently, several authors have analyzed the generator behavior in this situation [9-14]. Basically, the available unbalance control methods were based on the symmetrical component theory, which states that an unbalanced system is a combination of the positive and negative networks.

In [9], a new algorithm for generating the power reference for DPC was presented. It was shown that the oscillation term of electromagnetic torque can be eliminated without any sequence extraction. In [10], an improved vector control for DFIG under unbalanced grid voltage was proposed; two notch filters have been used to extract the positive and negative sequence of grid voltage. So according to a specified target like balanced stator currents, these components were applied to generate the reference rotor currents. In [11], an improved DPC strategy using two resonant controllers and a PI controller is proposed for maintaining constant stator power, to eliminate torque pulsation and to maintain sinusoidal stator current. The author in [12] introduced the unbalanced control strategy with the Vector Oriented Control (VOC) technique, in which the detrimental influence on the DFIG system caused by negative component of the grid voltage was also analyzed. Also, the system is designed to operate for different targets. The oscillation in power and torque are considerably reduced. In [13] and [14], a model for predictive direct power control with power compensation and three selective control targets was presented, -obtaining sinusoidal and symmetrical grid currents, removing active and reactive power ripples and mitigation torque oscillation- in order to enhance the control flexibility and performance of the DFIGs when the network is unbalanced.

This paper describes an algorithm for sensorless control of a DFIG-based wind turbine system under unbalanced grid voltage. This paper is organized as follows: section 2 describes the DFIG modeling; the response of DFIG under unbalanced condition is proposed in section 3 whereas the power compensation strategies are illustrated in section 4; the rotor position estimation strategy is presented in section 5; section 6 discusses the simulation results on a $2 \mathrm{MW}$ DFIG system to demonstrate the effect and performance of the proposed control algorithm; and finally, the conclusions are presented in section 7. 


\section{DFIG MODELING}

The equivalent circuit of a DFIG expressed in the stator stationary frame is shown in Fig. 2. The mathematical equations for a DFIG can be expressed as (1)

$$
\begin{aligned}
& V_{s}=R_{S} I_{s}+\frac{d \psi_{s}}{d t} \\
& V_{r}=R_{r} I_{r}+\frac{d \psi_{r}}{d t}-j \omega_{r} \psi_{r} \\
& \psi_{s}=L_{S} I_{s}+L_{m} I_{r} \\
& \psi_{r}=L_{m} I_{s}+L_{r} I_{r} \\
& T_{e}=\frac{3}{2} p \operatorname{Im}\left\{\psi_{s}^{*} I_{s}\right\}=\frac{3}{2} p\left\{\psi_{s} I_{s}-\psi_{s} I_{s} \alpha\right\} \\
& P_{s}=\frac{3}{2} \operatorname{Re}\left\{V_{s} I_{s}^{*}\right\}=\frac{3}{2}\left\{V_{s} I_{s}+V_{s} I_{s} \beta\right\} \\
& Q_{s}=\frac{3}{2} \operatorname{Im}\left\{V_{s} I_{s}^{*}\right\}=\frac{3}{2}\left\{V_{s} I_{s} I_{s}-V_{s \alpha} I_{s} \beta\right\}
\end{aligned}
$$

\section{RESPONSE OF DFIG UNDER UNBALANCED GRID VOLTAGE}

Under unbalanced grid conditions, the system variables contain double frequency components additionally. With the conventional decoupled power control and with no additional control measures in place, the control is ineffective since the stator and grid currents exhibit significant low frequency harmonics. As a consequence, there are severe oscillations in torque, active and reactive power, and the DC link voltage. According to the symmetrical component theory, and assuming no zero sequence components, if the grid supply is unbalanced, any three phase quantity, e.g., voltage, current, or flux, can be separated into the positive and negative sequence components as in (9)

$$
\begin{aligned}
& V_{s}=V_{s}^{+}+V_{s}^{-}=\left(V_{s \alpha}^{+}+V_{s \alpha}^{-}\right)+j\left(V_{s \beta}^{+}+V_{s \beta}^{-}\right) \\
& I_{s}=I_{s}^{+}+I_{s}^{-}=\left(I_{s \alpha}^{+}+I_{s \alpha}^{-}\right)+j\left(I_{s \beta}^{+}+I_{s \beta}^{-}\right) \\
& \psi_{s}=\psi_{s}^{+}+\psi_{s}^{-}=\left(\psi_{s \alpha}^{+}+\psi_{s \alpha}^{-}\right)+j\left(\psi_{s \beta}^{+}+\psi_{s \beta}^{-}\right)
\end{aligned}
$$

Substituting (8) and (9) into (6) and (7), we get

$$
\begin{aligned}
& P_{S}=\frac{3}{2}\left(P_{1}+P_{2}+P_{3}+P_{4}\right) \\
& Q_{S}=\frac{3}{2}\left(Q_{1}+Q_{2}+Q_{3}+Q_{4}\right)
\end{aligned}
$$

Where

$$
\begin{aligned}
& P_{1}=\frac{3}{2} \operatorname{Re}\left\{V_{s}^{+} I_{s}^{+*}\right\}=\frac{3}{2}\left\{V_{s \alpha}^{+} I_{s \alpha}^{+}+V_{s \beta}^{+} I_{s \beta}^{+}\right\} \\
& P_{2}=\frac{3}{2} \operatorname{Re}\left\{V_{s}^{-} I_{s}^{-*}\right\}=\frac{3}{2}\left\{V_{s \alpha}^{-} I_{s \alpha}^{-}+V_{s \beta}^{-} I_{s \beta}^{-}\right\}
\end{aligned}
$$




$$
\begin{aligned}
& P_{3}=\frac{3}{2} \operatorname{Re}\left\{V_{s}^{+} I_{s}^{-*}\right\}=\frac{3}{2}\left\{V_{s \alpha}^{+} I_{s \alpha}^{-}+V_{s \beta}^{+} I_{s \beta}^{-}\right\} \\
& P_{4}=\frac{3}{2} \operatorname{Re}\left\{V_{s}^{-} \cdot I_{s}^{+*}\right\}=\frac{3}{2}\left\{V_{s \alpha}^{-} I_{s \alpha}^{+}+V_{s \beta}^{-} I_{s \beta}^{+}\right\} \\
& Q_{1}=\frac{3}{2} \operatorname{Im}\left\{V_{s}^{+} \cdot I_{s}^{+*}\right\}=\frac{3}{2}\left\{V_{s \beta}^{+} I_{s \alpha}^{+}-V_{s \alpha}^{+} I_{s \beta}^{+}\right\} \\
& Q_{2}=\frac{3}{2} \operatorname{Im}\left\{V_{s}^{-} \cdot I_{s}^{-*}\right\}=\frac{3}{2}\left\{V_{s \beta}^{-} I_{s \alpha}^{-}-V_{s \alpha}^{-} I_{s \beta}^{-}\right\} \\
& Q_{3}=\frac{3}{2} \operatorname{Im}\left\{V_{s}^{+} I_{s}^{-*}\right\}=\frac{3}{2}\left\{V_{s \beta}^{+} I_{s \alpha}^{-}-V_{s \alpha}^{+} I_{s \beta}^{-}\right\} \\
& Q_{4}=\frac{3}{2} \operatorname{Im}\left\{V_{s}^{-} I_{s}^{+*}\right\}=\frac{3}{2}\left\{V_{s \beta}^{-} I_{s \alpha}^{+}-V_{s \alpha}^{-} I_{s \beta}^{+}\right\}
\end{aligned}
$$

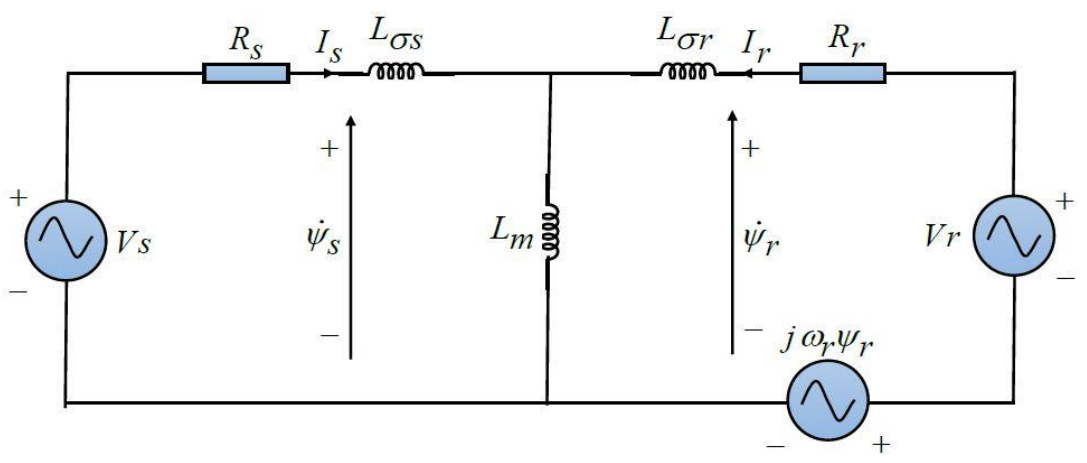

Fig. 2: Equivalent circuit of a DFIG in the stator stationary frame.

The pulsation terms $\mathrm{P}_{1}, \mathrm{Q}_{1}$ and $\mathrm{P}_{2}, \mathrm{Q}_{2}$ are constant at steady state, because they are composed by the same sequence product. However, terms $\mathrm{P}_{3}, \mathrm{Q}_{3}$ and $\mathrm{P}_{4}, \mathrm{Q}_{4}$ oscillate at twice the grid frequency pulsation, since they are composed of positive and negative sequence products.

Also with substituting the positive and negative sequence components of the stator current and flux into the expression (5), we obtain

$$
T_{e}=\frac{3}{2} p \operatorname{Im}\left\{\psi_{S}^{+*} I_{S}^{+}+\psi_{S}^{+*} I_{S}^{-}+\psi_{S}^{-*} I_{S}^{+}+\psi_{S}^{-*} I_{S}^{-}\right\}
$$

In addition, stator flux can be expressed using the stator voltage from (1) as

$$
\psi_{S}=\frac{j}{\omega_{S}}\left(R_{S} I_{S}-V_{S}\right)
$$

Substituting the flux from expressions (22) in torque equation (21), we get

$$
T_{e}=\frac{3}{2 \omega_{s}} p \operatorname{Re}\left\{V_{S}^{+} I_{S}^{+^{*}}-V_{S}^{-} I_{S}^{-*}-V_{S}^{-} I_{S}^{+*}+V_{S}^{+} I_{S}^{-*}+R_{S}\left(\left|I_{s}^{-}\right|^{2}-\left|I_{s}^{+}\right|^{2}\right)\right\}
$$

According to the active power expression (11), the torque equation (23) becomes

$$
T_{e}=\frac{3 p}{2 \omega_{S}}\left\{P_{1}-P_{2}+P_{3}-P_{4}+T_{0}\right\}
$$


Where

$$
T_{0}=R_{S}\left(\left|I_{S}^{-}\right|^{2}-\left|I_{S}^{+}\right|^{2}\right)
$$

It should be noted, in this study, that the DPC technique is adopted for both RSC and GSC, as enunciated in [1] and [15].

\section{RESPONSE OF DFIG UNDER UNBALANCED GRID VOLTAGE}

In an unbalanced condition, reference powers are generated based on the expression of instantaneous powers that include the steady state, sinusoidal, and cosine components of active and reactive powers. Reference powers for RSC can be generated based on different individual control targets such as minimizing the double frequency oscillations of sinusoidal or cosine terms of stator active or reactive power, electromagnetic torque, and negative sequence winding currents. In other words, in this section the following three objectives will be introduced and will be used

Target 1: Eliminating the double frequency pulsations of stator active and reactive power to make the instantaneous stator active and reactive power constant.

Target 2: Maintaining a constant electromagnetic torque in order to reduce the mechanical stress on the turbine system.

Target 3: Balancing the stator current to ensure balanced heating in the three phase stator windings.

\subsection{Active and Reactive Power Oscillation Cancellation Strategy (target 1)}

This control target is to allow the existence of negative sequence current components but eliminate the stator output active and reactive power ripples.

In order to obtain constant active and reactive power, both of the reference must be kept constant, thus the active and reactive power ripples must be zero, i.e. [9]

$$
\begin{gathered}
P_{3}+P_{4}=0 \\
Q_{3}+Q_{4}=0
\end{gathered}
$$

As a result, the required powers for compensation become

$$
\begin{aligned}
& P_{\text {ref }}=P_{\text {const }}=P_{1}+P_{2} \\
& Q_{\text {ref }}=Q_{\text {const }}=Q_{1}+Q_{2}
\end{aligned}
$$

According to (24) and (26), even if the stator active and reactive power pulsation can be removed by the unbalanced DPC, the torque pulsation will still exist.

\subsection{Torque Oscillation Cancellation Strategy (target 2)}

This objective is to mitigate the torque oscillation when the network is unbalanced. According to (24), the torque oscillation can be eliminated by imposing the requirement [9]

$$
P_{3}-P_{4}=0
$$

Which results in an electromagnetic torque, such that: 


$$
T_{e}=\frac{3 p}{2 \omega_{S}}\left\{P_{1}-P_{2}+T_{0}\right\}
$$

Under this situation, the required power and the reference stator active power are related by the following expression:

$$
P_{\text {ref }}=P_{\text {const }}+2 P_{3}=P_{\text {const }}+2 P_{4}
$$

Since the condition for torque oscillation cancellation in (30) is not related to reactive power, no compensation is needed for the reactive power; in other words, $Q_{r e f}=0$.

\subsection{Sinusoidal and Balanced Stator Current Exchanged with Grid (target 3)}

If $\mathrm{P}_{2}$ and $\mathrm{Q}_{2}$ are added to the original power references to obtain the new power references, $\mathrm{P}_{1}$ and $\mathrm{Q}_{1}$ can be forced to zero; that is, the negative sequence current is eliminated. In other words, $I_{S \alpha}^{-}$and $I_{s \beta}^{-}$have to be zero if $\mathrm{P}_{1}$ and $\mathrm{Q}_{1}$ are to be maintained as zero.

Therefore, the compensating power pulsations become [13]

$$
\begin{gathered}
P_{\text {ref }}=P_{\text {const }}+P_{4} \\
Q_{\text {ref }}=Q_{\text {const }}+Q_{4}
\end{gathered}
$$

In the above equation, $P_{\text {const }}$ and $Q_{\text {const }}$ are equal to the original power references under the balanced grid voltage condition.

\section{ROTOR POSITION ESTIMATION STRATEGY}

To increase the reliability of the grid synchronization process, it is important to implement the sensorless rotor position control. There are two main methods that have been used for the detection of the rotor position: 1) derived from a shaft sensor and, 2) derived from a sensorless algorithm. Sensorless operation is more desirable than using a shaft sensor, because the shaft sensor has several disadvantages related to the cost, cabling between the sensor and the controller, robustness, and maintenance. The rotor current of DFIGs is available for measurement, which is not possible in cage rotor induction machines. This provides more flexibility in designing sensorless control schemes for DFIGs.

Seen from the stator coordinate system, $\left(I_{r}\right)$ makes an angle $\theta_{S}$. Figure 3 shows the same rotor current makes an angle $\theta_{r}$ with the rotor axis. The problem, therefore, is to compute $\theta_{S}$ and $\theta_{r}$, so that $\left(\theta_{m}\right)_{e s t}=\left(\theta_{S}-\theta_{r}\right)$ can be determined.

Rotor current magnitude and unit templates of rotor currents aligned to rotor axis are calculated as [8]

$$
\begin{aligned}
& \left|I_{r}\right|=\sqrt{I_{r \alpha}^{2}+I_{r \beta}^{2}} \\
& \cos \theta_{r}=\frac{I_{r \alpha}^{2}}{\left|I_{r}\right|} \\
& \sin \theta_{r}=\frac{I_{r \beta}^{2}}{\left|I_{r}\right|}
\end{aligned}
$$


The rotor current unit templates $\left(\cos \theta_{s}, \sin \theta_{s}\right)$ aligned to the stator coordinate system has to be calculated. Using previous unit template samples two phase rotor currents $\left(I_{r \alpha}, I_{r \beta}\right)$ are converted into stator coordinates as

$$
\begin{aligned}
& I_{r s \alpha}^{\prime}[k]=I_{r \alpha}[k] *\left(\cos \theta_{m}[k-1]\right)_{e s t}-I_{r \beta}[k] *\left(\sin \theta_{m}[k-1]\right)_{e s t} \\
& I_{r s \beta}^{\prime}[k]=I_{r \alpha}[k] *\left(\cos \theta_{m}[k-1]\right)_{e s t}+I_{r \beta}[k]^{*}\left(\sin \theta_{m}[k-1]\right)_{e s t}
\end{aligned}
$$

Where $\mathrm{k}$ is the present sample, $(\mathrm{k}-1)$ is the previous sample, the superscript ' indicates the intermediate variable. Where $\left(\cos \theta_{m}[k-1]\right)_{e s t}$ and $\left(\sin \theta_{m}[k-1]\right)_{e s t}$ are the unit vectors of rotor position estimated in the previous sample.

In terms of the stator and rotor currents, the stator flux magnetizing current $\left(I_{m s}\right)$ in the stator coordinate system can be expressed as

$$
\begin{aligned}
& I_{m s \alpha}^{\prime}[k]=\left(1+\sigma_{s}\right) I_{s \alpha}[k]+I_{r s \alpha}^{\prime}[k] \\
& I_{m s \beta}^{\prime}[k]=\left(1+\sigma_{s}\right) I_{s \beta}[k]+I_{r s \beta}^{\prime}[k] \\
& I_{m s}^{\prime}=\sqrt{I_{m s \alpha}^{\prime 2}+I_{m s \beta}^{\prime 2}}
\end{aligned}
$$

Where $\sigma_{s}=\left(L_{s} L_{r}-L_{m}^{2}\right) / L_{s} L_{r}$ is the stator leakage factor.

The stator flux magnetizing current vector $\left(I_{m s}\right)$ makes an angle of $(\theta-90)$ with the stator axis. The expression of $\alpha, \beta$ components can be written as

$$
\begin{aligned}
& I_{m s \alpha}=I_{m s} \sin \theta \\
& I_{m s \beta}=-I_{m s} \cos \theta
\end{aligned}
$$

Where

$$
\begin{aligned}
& \sin \theta=\frac{V_{s \beta}}{\sqrt{V_{s \alpha}^{2}+V_{s \beta}^{2}}} \\
& \cos \theta=\frac{V_{s \alpha}}{\sqrt{V_{s \alpha}^{2}+V_{s \beta}^{2}}}
\end{aligned}
$$

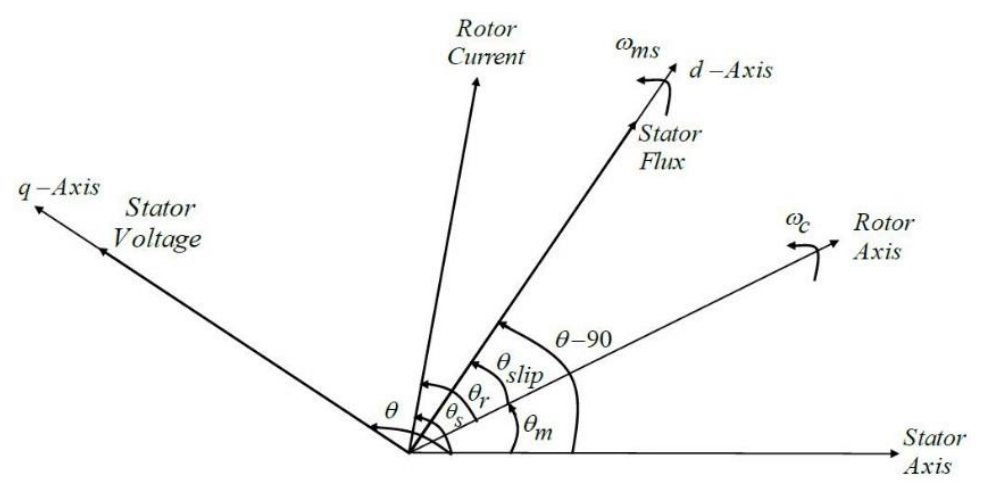

Fig. 3: Phasor diagram for rotor position estimation strategy [8]. 
Using above $I_{m s}$ and measured value of stator current $\left(I_{s}\right)$, the rotor currents can be computed in the stationary frame as

$$
\begin{aligned}
& I_{r s \alpha}=I_{m s \alpha}-\left(1+\sigma_{s}\right) I_{s \alpha} \\
& I_{r s \beta}=I_{m s \beta}-\left(1+\sigma_{s}\right) I_{s \beta} \\
& \left|I_{r}^{s}\right|=\sqrt{I_{r s \alpha}^{2}+I_{r s \beta}^{2}}
\end{aligned}
$$

The unit vectors of rotor current in stationary coordinate system are given by

$$
\begin{aligned}
& \sin \theta_{s}=\frac{I_{r s} \beta}{\left|I_{r}^{S}\right|} \\
& \cos \theta_{s}=\frac{I_{r s} \alpha}{\left|I_{r}^{s}\right|}
\end{aligned}
$$

Equations (36-37) and (50-51) represent the unit vectors in the two reference frames, the former rotating at synchronous speed and, the latter at slip frequency. The unit vectors pertaining to the rotor position $\left(\theta_{m}\right)_{e s t}=\left(\theta_{S}-\theta_{r}\right)$ can now be easily computed

$$
\begin{gathered}
\cos \left(\theta_{m}\right)_{e s t}=\cos \left(\theta_{s}-\theta_{r}\right)=\cos \left(\theta_{s}\right) \cos \left(\theta_{r}\right)+\sin \left(\theta_{s}\right) \sin \left(\theta_{r}\right) \\
\sin \left(\theta_{m}\right)_{e s t}=\sin \left(\theta_{s}-\theta_{r}\right)=\sin \left(\theta_{s}\right) \cos \left(\theta_{r}\right)-\cos \left(\theta_{s}\right) \sin \left(\theta_{r}\right)
\end{gathered}
$$

The unit vectors of slip angle are used in below equation for finding the stator flux vector in rotor reference frame. This is equation as:

$$
\psi_{s}^{r}=\left(\psi_{s \alpha}+j \psi_{s \beta}\right)\left\{\cos \left(\theta_{m}\right)_{e s t}-j \sin \left(\theta_{m}\right)_{e s t}\right\}
$$

Where the stator flux linkages are calculated as:

$$
\begin{aligned}
& \psi_{s \alpha}=\int\left(V_{s \alpha}-R_{s} I_{s \alpha}\right) d t \\
& \psi_{s \beta}=\int\left(V_{s \beta}-R_{s} I_{s \beta}\right) d t
\end{aligned}
$$

Figure 4 shows the schematic diagram of the improved control scheme for sensorless DPC of grid connected DFIGs when the network voltage is unbalanced. There are no reports related to the use of sensorless algorithms for DFIG control when the network voltage is unbalanced.

Also, Fig. 4 shows the proposed compensation methods for powers, torque, and stator current oscillation, as well as the rotor position estimation strategy under unbalanced grid voltage conditions. It can be seen from Fig. 4, that the compensating powers are calculated according to Eqn. (28), (29) or (32) or (33), (34), as shown in the dotted line block. A notch filter turned at double grid frequency has been adopted to extract positive and negative sequence stator current and voltage. The filter may involve some amplitude and phase errors that may worsen the control effect. However, since the notch filter is just used to calculate the compensating power and it lies out of the power control loop, the inherent defects caused by sequential decomposition, such as slow dynamic response and low bandwidth of the control loop, could be avoided. 


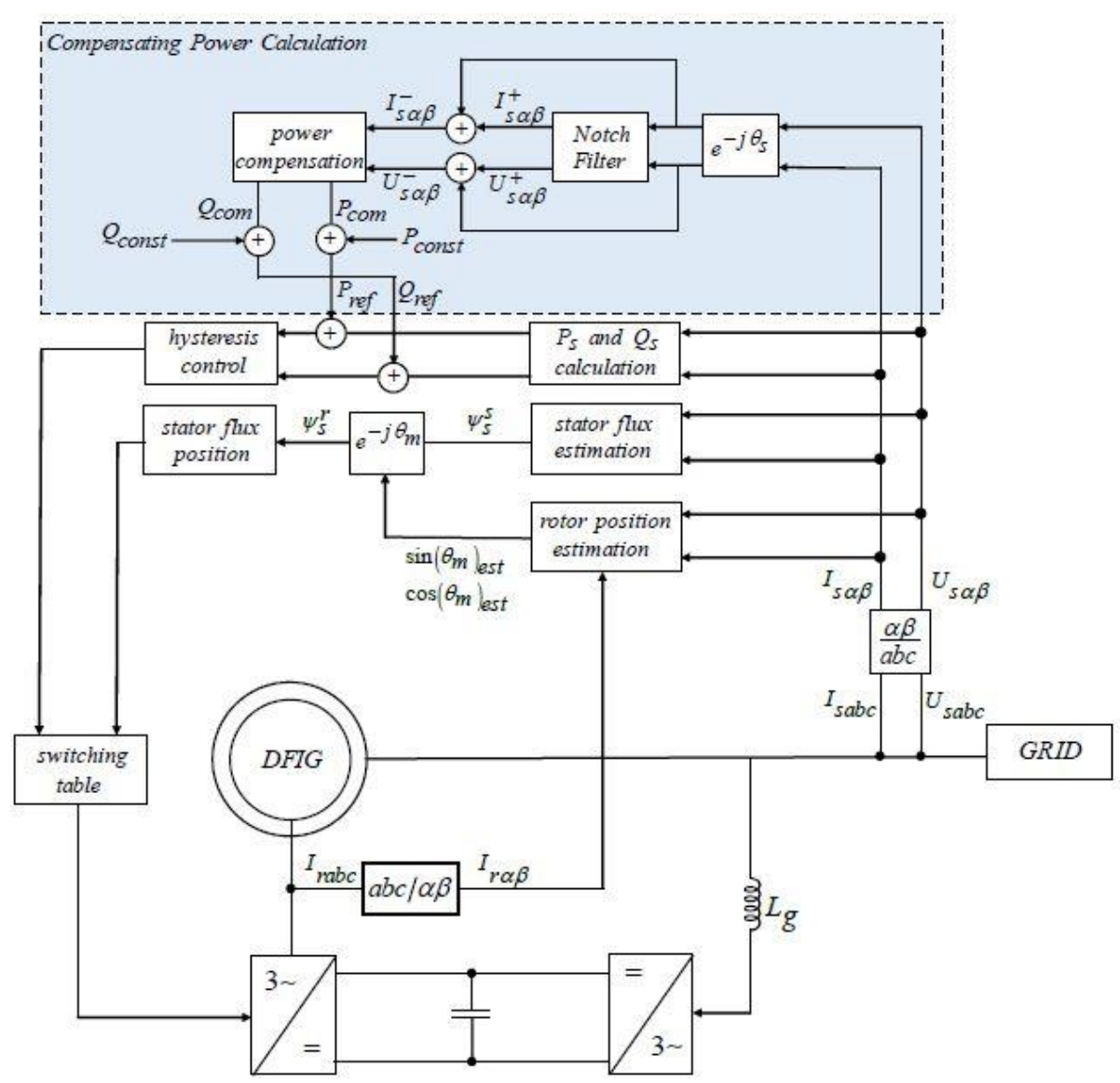

Fig. 4: The proposed schematic diagram of the sensorless DPC for DFIG under unbalanced condition.

\section{SIMULATION RESULTS}

Simulations of the proposed control strategy for a DFIG based wind power generation system were carried out using MATLAB/Simulink and Fig. 5 shows the scheme of the implemented system. The DFIG is rated at $2 \mathrm{MW}$ with its parameters given in Table 1 . The nominal converter DC-link voltage was set at $1200 \mathrm{~V}$. During simulation, the sampling frequency is $20 \mathrm{KHZ}$ and the bandwidths of the active and reactive power hysteresis controllers are set at $\pm 4 \%$ of the rated generator power of $2 \mathrm{MW}$.

Table 1: Parameters of the DFIG simulated

\begin{tabular}{cc}
\hline Parameters & Value \\
\hline Rated Power & $2 \mathrm{MW}$ \\
Stator Voltage & $690 \mathrm{~V}$ \\
Stator/rotor turns ratio & 0.3 \\
$\mathrm{Rs}$ & $0.0108 \mathrm{pu}$ \\
$\mathrm{Rr}$ & $0.0121 \mathrm{pu}$ (refers to the stator) \\
$\mathrm{Lm}$ & $3.362 \mathrm{pu}$ \\
$\mathrm{L}_{\sigma \mathrm{s}}$ & $0.102 \mathrm{pu}$ \\
$\mathrm{L}_{\sigma \mathrm{r}}$ & $0.11 \mathrm{pu}$ (refers to the stator) \\
Lumped inertia constant & 0.5 \\
Number of pole pairs & 2 \\
\hline
\end{tabular}


The performance of the system will be analyzed under a steady-state operation condition. The grid voltage unbalance programmed for this experiment is shown in Fig. 6 and its values are $\left(V_{s a}=555^{V}<0^{0}, V_{s b}=484.2^{V}<-113^{0}, V_{s c}=557.5^{V}<-231^{0}\right)$. The DFIG was assumed to be in speed control, meaning that the rotor speed is set externally, as the large inertia of the wind turbine results in a slow change of rotor speed. The stator active and reactive power references are set to 0.166 and 0.33 p.u. at a constant speed of 0.73 p.u. where the synchronous speed was defined as 1 unit.

In the second half of the experiment, the behavior of the machine side magnitudes and the grid side magnitudes are presented when the system is commanded with the oscillation cancellation strategies, as proposed in section 4. Before this, in the first half of the experiment, the cancellation strategies are disabled.

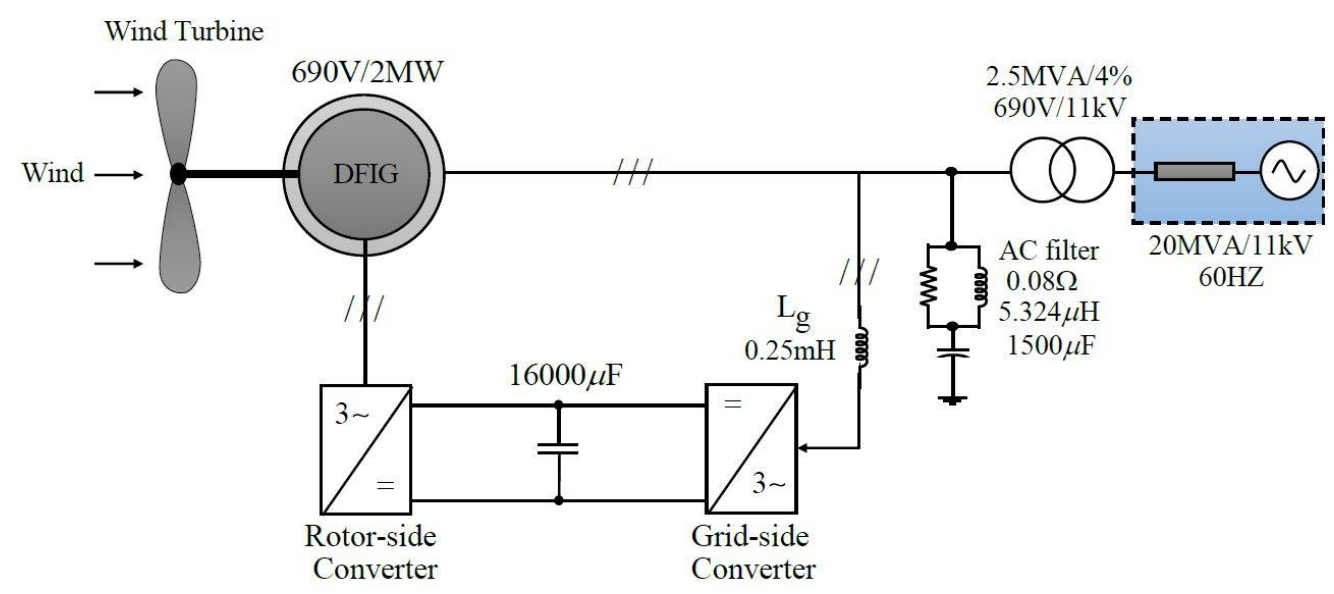

Fig. 5: Scheme of the simulated system.

As shown in the previous section, Target 3 gives good attenuation of both torque and active power oscillation. For Target 1, while the active power oscillation is greatly reduced, the torque pulsation is relatively large. Similar observations can also be noticed for Target 2. The selection of the control target is highly dependent on the design of the turbine system and the operation of the network.

In Fig. 7, Target 1 (Active and reactive power oscillation cancellation strategy) was selected as the control objective.

In Fig. 8, Target 2 (Electromagnetic torque oscillation cancellation strategy) was selected as the control objective. The second half, of Fig. 8(a) shows the power tracking behavior in order to cancel the electromagnetic torque oscillation. Figure 8(b) shows the current exchanged through the stator under these operation conditions. In the simulation results, a strong deterioration of the currents can be observed before $0.15 \mathrm{~s}$. This fact is due to the oscillating behavior of the electromagnetic torque during this first half of the experiment. In addition, when the torque oscillation cancellation strategy is operating, the stator currents are unbalanced but sinusoidal.

In Fig. 9, Target 3 of the power compensation scheme is implemented. As shown in Fig. 9, there are oscillating components in both the active and reactive powers because of the two oscillating terms, $\mathrm{P} 4$ and $\mathrm{Q} 4$, added to the original constant active and reactive powers. However, these eliminate the negative sequence current. As a result, the stator current becomes quite sinusoidal and symmetric, thus power quality is improved significantly. 
Simulation of the Stator flux position in the rotor reference frame, for cases with and without the rotor position sensor, with constant rotor speed were carried out and the results are shown in Fig. 10 (a) and (b) for rotor speeds of 1.2 and 0.8 p.u. respectively. Also, Fig. 10 (c) shows the result of the proposed method operating with variable speed from 1.2 p.u. to 0.8 p.u. It can be seen that the stator flux position in the rotor reference frame can be correctly estimated and there is very little deterioration in system performance with the sensorless scheme. In the rotor position sensorless control investigation, the rotor encoder was still installed on the shaft, but its position output was not used in the system control. Instead, it was used for comparison with the estimated stator flux position values.

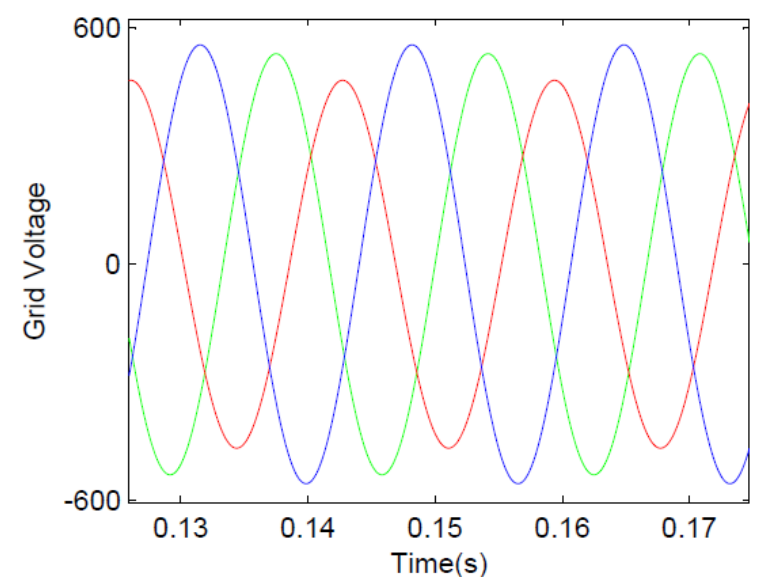

Fig. 6: Unbalanced grid voltage.
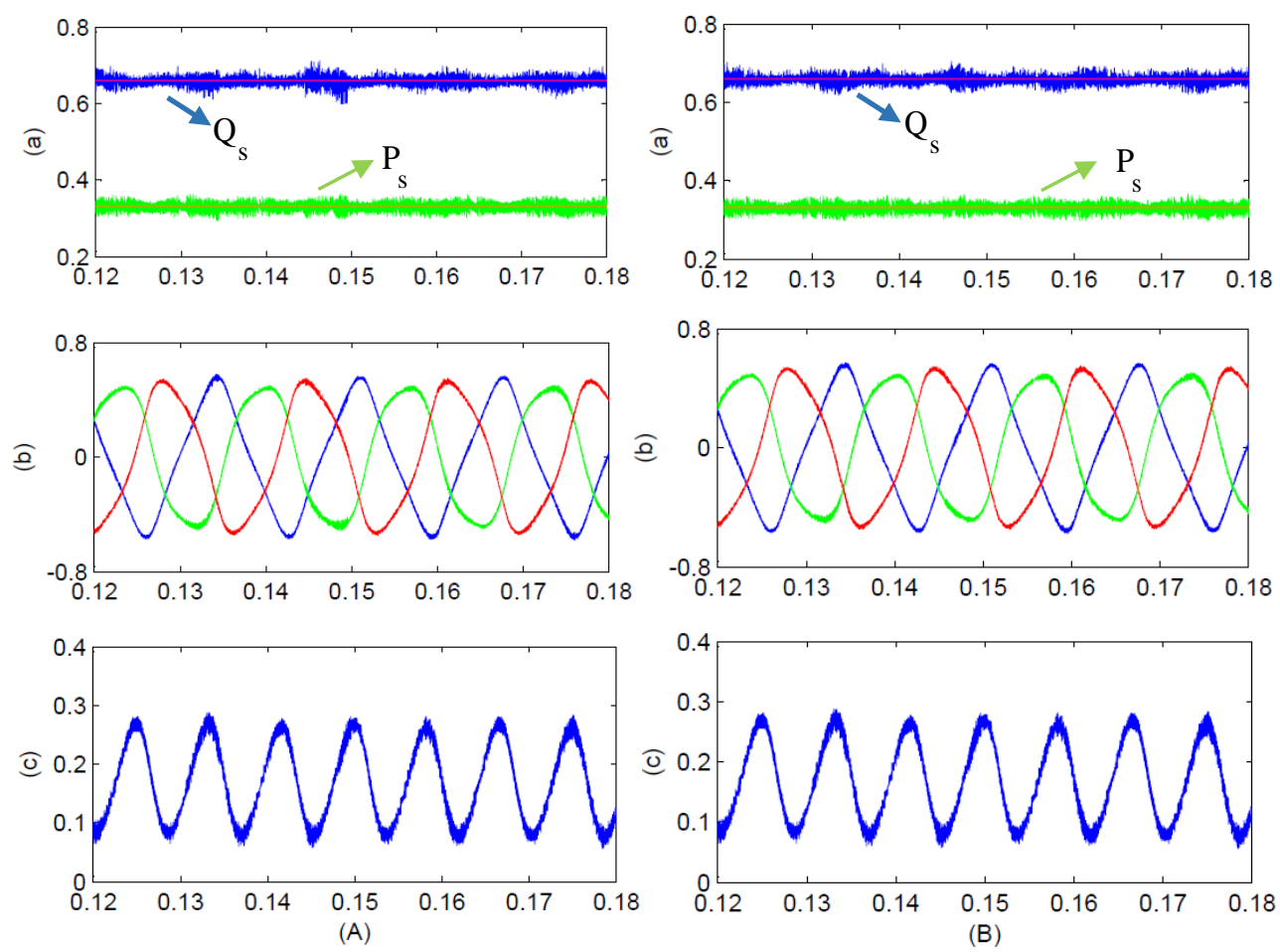

Fig. 7: Simulation results comparison with $[\mathrm{B}]$ and without $[\mathrm{A}]$ rotor position sensor, with power compensation for target 1.

(a) Stator active, and reactive powers (p.u). (b) stator currents (p.u).

(c) electromagnetic torque (p.u). 

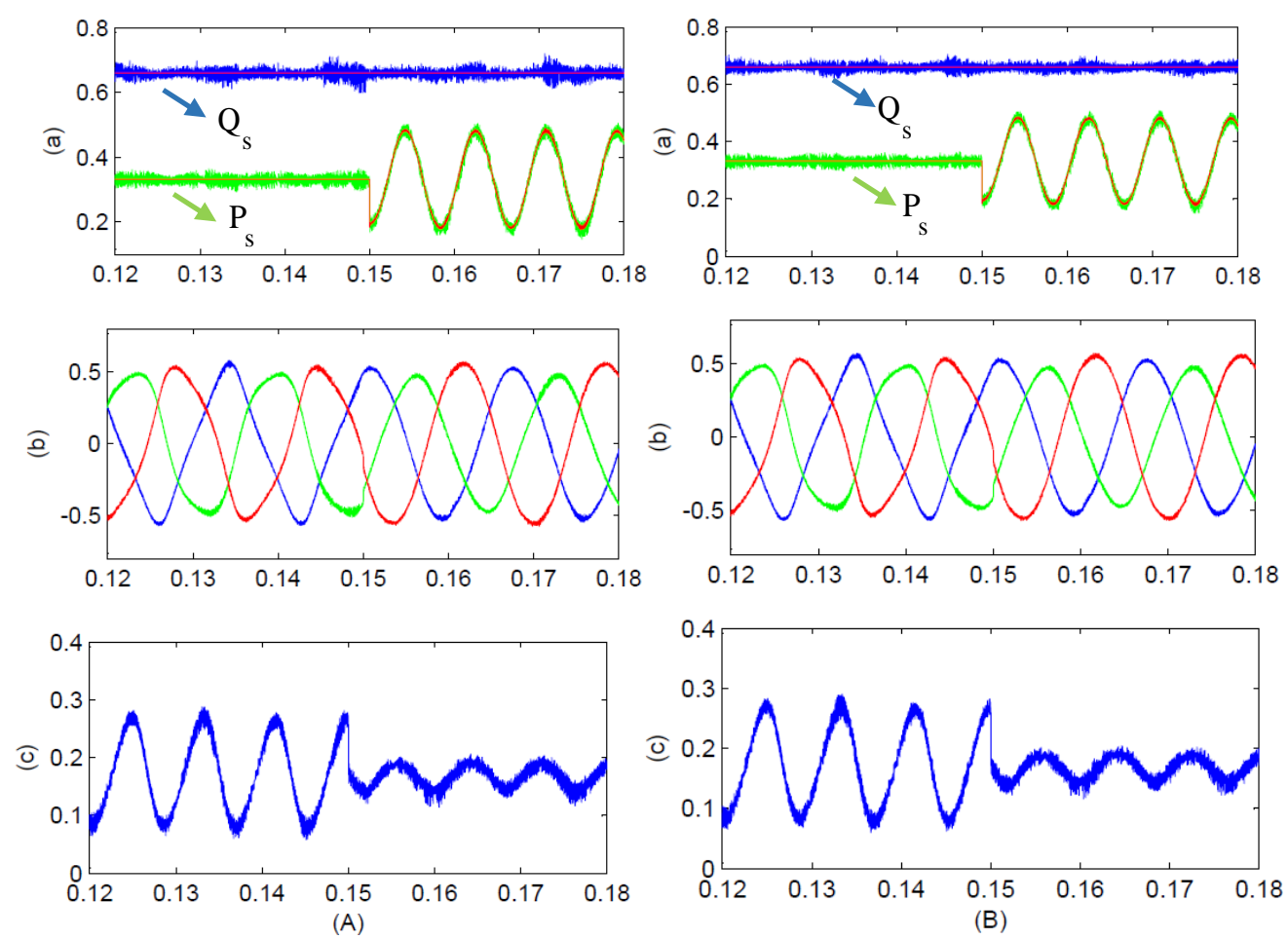

Fig. 8: Simulation results comparison with $[\mathrm{B}]$ and without $[\mathrm{A}]$ the rotor position sensor, with power compensation for target 2 .

(a) Stator active, and reactive powers (p.u). (b) stator currents (p.u).

(c) electromagnetic torque (p.u).
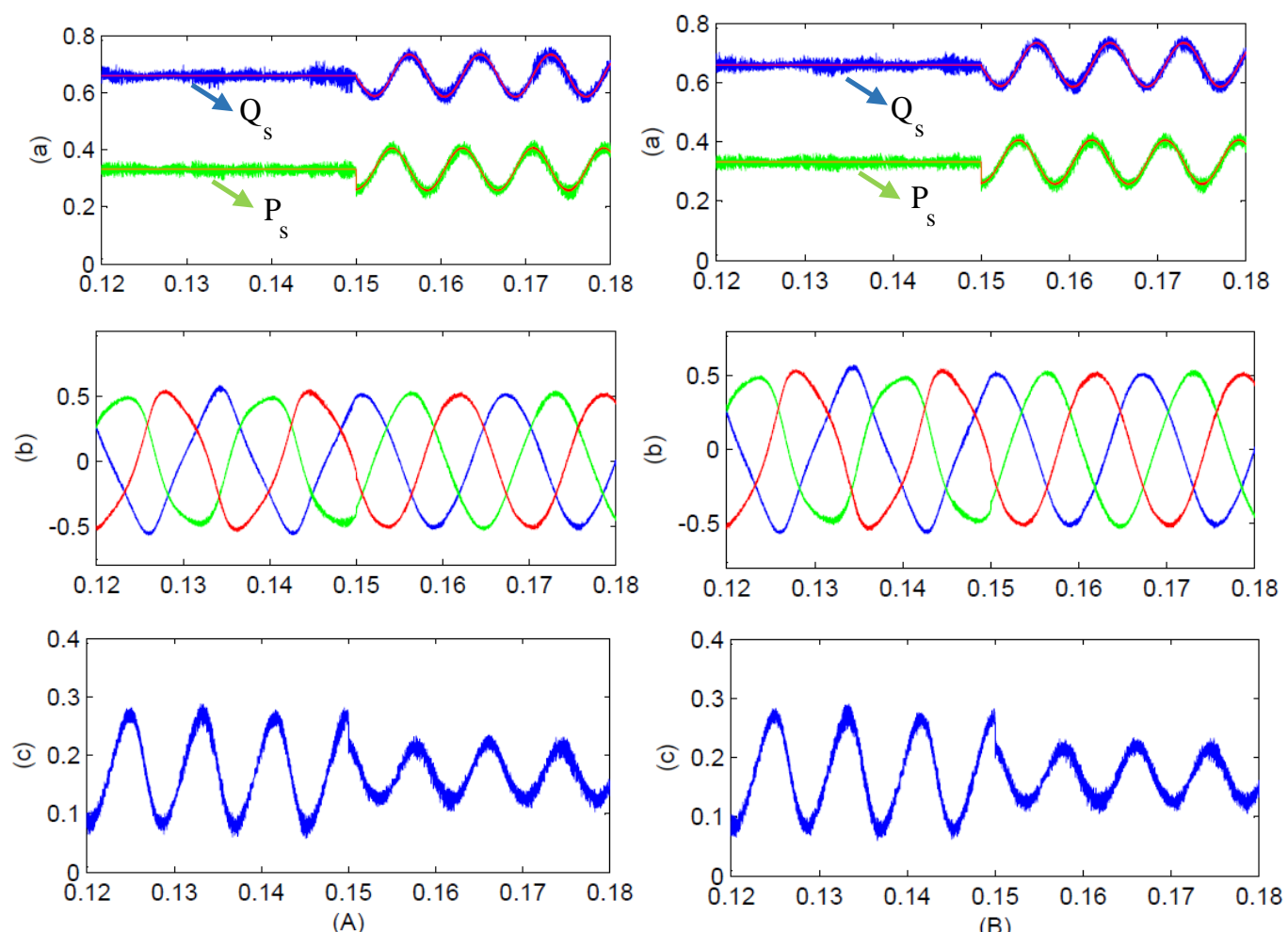

Fig. 9: Simulation results comparison with $[\mathrm{B}]$ and without $[\mathrm{A}]$ rotor position sensor, with power compensation for target 3.

(a) Stator active, and reactive powers (p.u). (b) stator currents (p.u).

(c) electromagnetic torque (p.u). 

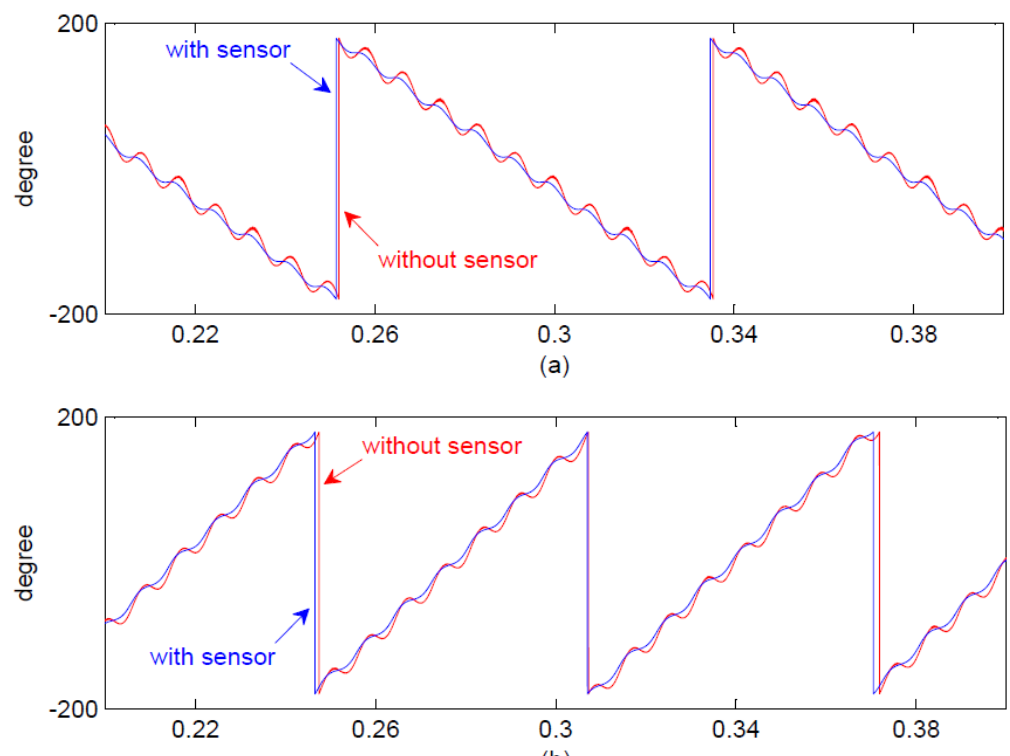

(b)

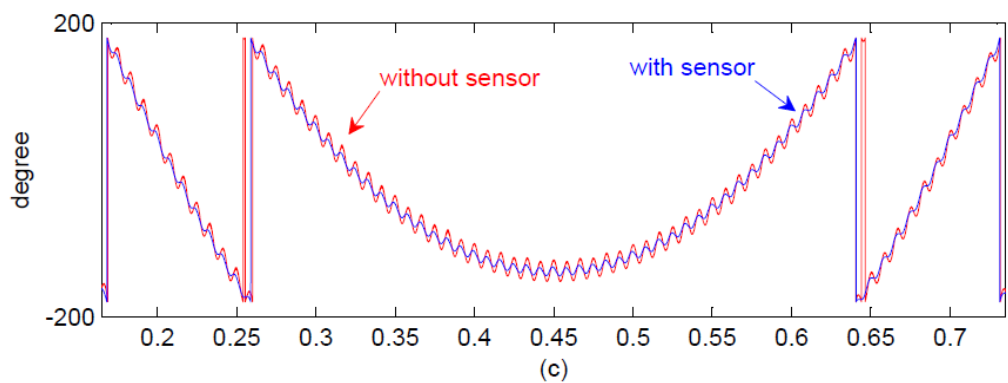

Fig. 10: Stator flux position in the rotor reference frame for with and without rotor position sensor under constant and variable rotor speed.

(a) Constant speed 1.2 (p.u). (b) Constant speed 0.8 (p.u). (c) Variable speed from 1.2 to 0.8 (p.u).

\section{CONCLUSION}

This paper has presented a new control strategy for DFIG-based wind energy generation systems operating under unbalanced network conditions. This method used a simple position-sensorless algorithm to eliminate the rotor position sensor. The simulation results show the accuracy of the proposed rotor position estimation strategy in all relevant situations. Also, stator active and reactive powers and generator electromagnetic torque have been fully defined under an unbalanced voltage supply, which indicates that significant pulsation at twice the supply frequency could exist. Methods for providing enhanced system control and operation for DFIG-based wind turbines during network unbalance i.e., power, torque, or stator current oscillation minimization, are identified. These three selectable control targets are used for compensation.

\section{REFERENCES}

[1] Lie Xu, Phillip Cartwright. (2006) Direct Active and Reactive Power Control of DFIG for Wind Energy Generation. IEEE Trans. Energy Conv., 21(3):750-758.

[2] Dawei Zhi, Lie Xu. (2007) Direct Power Control of DFIG With Constant Switching Frequency and Improved Transient Performance. IEEE Trans. Energy Conv., 22(1):110-118.

[3] Dawei Zhi, Lie Xu, Barry W. Williams. (2010) Model-Based Predictive Direct Power Control of Doubly Fed Induction Generators. IEEE Trans. Power Electron., 25(2):341-351. 
[4] Yongchang Zhang, Jiefeng Hu, Jianguo Zhu. (2014) Three-Vectors-Based Predictive Direct Power Control of Doubly Fed Induction Generator for Wind Energy Application. IEEE Trans. Power Electron., 29(7):3485-3500.

[5] Jiabing Hu, Heng Nian, Bin Hu, Yikang He, Zhu ZQ. (2010) Direct Active and Reactive Power Regulation of DFIG Using Sliding-Mode Control Approach. IEEE Trans. Energy Conv., 25(4):1028-1039.

[6] Etienne Tremblay, Sergio Atayde, Ambrish Chandra. (2011) Comparative Study of Control Strategies for the Doubly Fed Induction Generator in Wind Energy Conversion Systems: A DSP-Based Implemention Approach. IEEE Trans. Sustain. Energy, 2(3):288-299.

[7] Mohammad Verij Kazemi, Ahmad Sadeghi Yazdankhah, Hossein Madadi Kojabadi. (2010) Direct power control of DFIG based on discrete space vector modulation. 35(5):1033-1042.

[8] Rajib Datta, Ranganathan VT. (2001) A Simple Position Sensorless Algorithm for Rotor Side Field Oriented Control of Wound Rotor Induction machine. IEEE Trans. Ind. Electron., 48(4):786-793.

[9] Gonzalo Abad, Miguel Angel Rodriguez, Grzegorz Iwanski, Javier Poza. (2010) Direct Power Control of Douby-Fed-Induction-Generator-Based Wind Turbine Under Unbalanced Grid Voltage. IEEE Trans. Power Electron., 25(2):442-452.

[10] Lie Xu, Yi Wang. (2007) Dynamic Modeling and Control of DFIG-Based Wind Turbines Under Unbalanced Network Condition. IEEE Trans. Power Syst., 22(1):314-323.

[11] Heng Nian, Yipeng Song, Peng Zhou, Yikang He. (2011) Improved Direct Power Control of a Wind Turbine Driven Doubly Fed Induction Generator During Transient Grid Voltage Unbalance. IEEE Trans. Energy Conv., 26(3):976-986.

[12] Lie Xu. (2008) Coordinated Control of DFIG's Rotor and Grid Side Converters During Network Unbalance. IEEE Trans. Power Electron., 23(3):1041-1049.

[13] Jiefeng Hu, Jianguo Zhu, David G. Dorrell. (2015) Predictive Direct Power Control of Doubly Fed Induction Generators Under Unbalanced Grid Voltage Conditions for Power Quality Improvement. IEEE Trans. Sustain. Energy, 6(3):943-950.

[14] Jiefeng Hu, Jianguo Zhu, David G. Dorrell. (2014) Model-Predictive Direct Power Control of Doubly Fed Induction Generators Under Unbalanced Grid Voltage Conditions in Wind Energy Conditions. IET Renew. Power Gener., 8(6):687-695.

[15] Toshihiko Noguchi, Hiroaki Tomiki, Seiji Kondo, Isao Takahashi. (1998) Direct Power Control of PWM Converter Without Power-Source Voltage Sensors. IEEE Trans. Ind. Applicat., 34(3):473-479.

\section{NOMENCLATURE}

$V_{s}, V_{r}$
$I_{s}, I_{r}$
$R_{s}, R_{r}$
$L_{\sigma s}, L_{\sigma r}$
$L_{m}$
$\psi_{s}, \psi_{r}$
$P_{s}, Q_{s}$
$T_{e}$
$\omega_{r}, \omega_{s}, \omega_{m}$
$p$
$*$

Stator and rotor voltage vectors

Stator and rotor current vectors

Stator and rotor resistance

Stator and rotor leakage inductance

Magnetizing inductance

Stator and rotor flux vectors

Stator active and reactive powers

Electromagnetic torque

Rotor, stator and slip speeds

Number of pole pairs

Donates the complex conjugate operation 